\title{
Exploring Socioeconomic Impacts of REDD-plus Pilot Program to Rural Livelihoods: Comparative Study of Yedashae and Oaktwin Townships in Bago Region of Myanmar
}

\author{
Kay Zin Than', Yali Wen¹ , Zaw Zaw²
}

\author{
${ }^{1}$ School of Economics and Management, Beijing Forestry University, No. (35), Qinghua East Road, Haidian \\ District, Beijing, P.R. China, Post code -100083 \\ ${ }^{2}$ Forest Research Institute, Forest Department, Nay Pyi Taw, Myanmar
}

\begin{abstract}
Reducing Emissions from Deforestation and Forest Degradation (REDD-plus) was evolved to provide incentives for the enhancement of carbon stock through conservation of forests. There are concerns about the potential impacts of REDD-plus on local livelihoods. This article accesses the socioeconomic impacts of two townships within the REDD-plus pilot project through using households' data from control and intervention villages. It found that REDD-plus pilot program had no significant impact on livelihood resources but relatively contributed to some extent for the development of physical capitals, particularly in terms of community awareness raising in intervention villages. The study revealed that $63 \%$ of households in intervention villages were pursuing "Forests and Daily Labor" Livelihood Strategy (LS) in which 54\% of households were using "Human and NTFPs" capitals. Meanwhile, in control villages, $27 \%$ of households were following "Forest and Wage Labor" Livelihood strategies (LS) in which $31 \%$ of households were depending on forest resources. Most of the households in intervention villages depend on the non-timber forest resources (NTFPs) for their livelihoods and they do not have enough income for their welfare. For control villages, households were pursuing daily labor for their livelihood and they also had to depend on forest resources for their subsistence and commercial purposes. This study also found that the sole dependency of forest resources for livelihood could not create standalone livelihood strategy in the area of high poverty and forest dependency rate. This study recommends Community Forestry (CF) as a policy framework which should be used for the integration of REDD-plus activities to the community livelihood development. Moreover, this study encourages inter-sectoral dialogue for the cooperation among agencies, linedepartments to ensure REDD-plus implementation benefits to local communities' livelihood resources.
\end{abstract}

Keywords: REDD-plus, socioeconomic impacts, livelihood strategies, livelihood resources, pilot program, Myanmar

\section{Introduction}

The Republic of the Union of Myanmar, with a total area of $676,577 \mathrm{~km}^{2}$, is situated mainly in the tropic of continental Southeast Asia. Ecosystems with lots of genetic diversities can be found in Myanmar's forests because of the tropical monsoon circulating system and its varied topography throughout the country. Among them, about 1,180 species of vascular plants including angiosperms and gymnosperms, 96 species of bamboo, 37 species of rattan and 841 species of medicinal plants have been recorded so far (Forest Department, 2014). According to forest resource assessment (2015), about 42.92 percent of the total land area is still covered with forest. Forest resources are the most critical and principal suppliers for livelihoods of people and national economy as well. The total population of the country is about 51 millions and 68 $\%$ of this population were classified by the World bank as rural people who residing in areas through depending heavily on the forests for their basic needs, especially for shelter, fodder, fuel wood, seasonal

This article is published under the terms of the Creative Commons Attribution License 4.0 Author(s) retain the copyright of this article. Publication rights with Alkhaer Publications.

Published at: http://www.ijsciences.com/pub/issue/2016-03/

DOI: 10.18483/ijSci.966; Online ISSN: 2305-3925; Print ISSN: 2410-4477 
food and hunting for their livelihoods (Population Census, 2014). They look for their livelihood especially for agricultural land and/or extraction of forest products. Since 1995, Myanmar Forest Department had adopted six main policy imperatives for national forestry sector development. One of the main policy imperatives describes that basic needs of the local people for fuel, shelter, food and recreation can be fulfilled through the forestry sector development. In line with the policy imperatives, different types of plantations such as community forestry plantations, village supply plantations and agroforestry plantations have been establishing yearly for the consideration of the needs of local people and economic support of the country. On the other hand, many forests and forest products have been depleting due to excessive extraction of forest resources in terms of legal and illegal ways for variety of purposes. Since 1984, massive scale reforestation programs have been undertaken as an effective measure to fulfill the increasing timber demands and to conserve the deteriorated forest land commencing in the East Bago Yoma region, which is widely known as "Home of Teak" in Myanmar (Forest Department, 2014). Plantations were established on the land of reserved forest under the management of Forest Department. The forest occupants and the landless poor participated in those programs. After several decades, as one of the negative impacts of the reforestation programs, the encroachment of rural communities in reserved forest areas for their livelihoods is the main challenge to be handled in the context of sustainable management of forests in Myanmar. In Myanmar, one of the developing countries in Southeast Asia, occurrence of deforestation over time can be pointed out through the high gap between the structural deforestation and observed deforestation which have been occurred because of the domestic policies and market failure to avoid deforestation (P. Combes Motel et al., 2008). Deforestation has significant impact not only in Myanmar but also in global context. Accordingly, deforestation and forest degradation processes will become significant net sources of $\mathrm{CO}_{2}$ emission by 2050, which can cause climate change impacts such as sea level rising, polar ice cap melting, earth's surface warming, and so on (IPCC, 2007). Although the strong policy framework and functioning institutional structures, management system for national forests are in place, Myanmar is also facing with serious deforestation problems like other developing countries.

\subsection{REDD-plus in Myanmar}

Emissions from deforestation and forest degradation amounted to $17.4 \%$ of total emissions from other sectors and hence, tropical deforestation has global significance impacts on climate change (IPCC, 2007). On December 2007, United Nations
Framework Convention on Climate Change (UNFCCC) introduced Reduced Emissions from Deforestation and Forest Degradation (REDD) mechanism, short term for significantly reducing green house gas emissions contributing to mitigate the impacts of global climate change and to reduce carbon emission especially from forestry sector. REDD-plus is designed for the carbon credit incentives based on the performance of policies and implementing activities concerning with five major activities such as reducing emission from deforestation and forest degradation, conservation of forest, sustainable management of forest (SFM) and enhancement of forest carbon stock. REDD-plus mechanism is originally come out for climate change mitigation and later, it is also aimed to contribute to SFM and socioeconomic development of forest dependent local communities. Because of its potential to reduce greenhouse gas emissions while simultaneously benefiting local communities and biodiversity, it has been greatly expected that REDDplus is an appropriate solution to reduce deforestation, to conserve biodiversity, to improve socioeconomic of pro-poor forest dependent communities, to mitigate climate change and so on. However, there still have many criticisms on REDDplus projects that are land-based carbon projects whether or not it is good for local people, biodiversity and ecosystem services.

On December 2011, Myanmar joined UN-REDD Programme and became one of the UN-REDD partner countries and has quickly taken steps to start implementing REDD-plus readiness activities. Decision 1/CP16 of the UNFCCC on REDD-plus has encouraged countries to initiate readiness and demonstration activities (UNFCCC, 2010). REDDplus readiness includes actions aimed to develop technical and institutional capacity in developing countries. REDD-plus readiness activities have being carried out in over 75 countries, with an estimated US\$ 7.2 billion committed to REDD-plus since 2008 (Creed and Nakhooda, 2011). As a National Level REDD-plus achievement, Myanmar Readiness Proposal Preparation (RP-P) was developed with the support of Norwegian Government in 2013 through series of national workshops and consultation meetings. Currently, Myanmar has been implementing the components of REDD+ Readiness Roadmap at national level with the coordination of UN-REDD agencies, namely UNDP, UNEP and FAO since January 2015. Meanwhile, Myanmar has been requested to implement REDD+ piloting projects at district and local levels with the cooperation of foreign governments and/or international organizations such as ITTO, Korea Forest Service, RECOFTC, ICIMOD, FFPRI, AAS Co., Ltd etc. As REDD-plus is still a readiness stage in Myanmar, raising awareness and building capacity 
of multi-stakeholders, establishing piloting projects at district and local levels can contribute to the successful implementation of nationwide REDD-plus programs. REDD-plus projects are in many ways similar to past forest conservation initiatives (Tacconi et al., 2012). Lots of Payment for Ecosystem Services (PES) programmes has been implementing worldwide and there are also many scholars analyzing effects of these different PES alternative options on local community's livelihood. REDD-plus policy concerning with community's livelihood development can be formulated on those successful framework of PES scheme not only to support raising incomes of local community but also to ensure sustainability of environmental outcomes in costeffective ways. Groom et al., 2010 and B. Groom and C. Palmer, 2012 stated that alternative off-farm income activities created by the PES programmes can reduce poverty in some extent but people's freedom of choice in term of volunteering their land and livelihood should be paid more attention to a REDDplus scheme. Lack of autonomy in household decision making and insufficient government compensation leads to unwelcome and unwanted shift in livelihood. Some studies have discussed benefit sharing among local stakeholders and communities (Corbera et al., 2007, Peskett, 2011, Luttrell et al., 2012 and M. Skutsh, 2012). However, only a few studies have analyzed benefit distribution in PES or REDD-plus pilot projects (Caplow et al., 2011) including direct and indirect benefits, within the stakeholder group that bears cost of conservation (Corbera et al., 2007).

REDD-plus attracts global support because of its potential incentives for the conservation of forests and biodiversities through generating new income stream for rural poor. At the same time, REDD-plus (at both project and national scale) remains highly controversial that the projects or programs will emphasize land use and carbon emission for potential funding but there could not have real consequences for local people (Jagger et al., 2009). There might be potential negative impacts on socioeconomic of local people such as restrictions on local community to access forest resources for their subsistence needs without due consideration in implementation of REDD-plus activities. REDD-plus projects and programs can be recognized for their contributions to learning about environmental, economic and social equity. As REDD-plus is on-going process for readiness stage in Myanmar, it is very important to know the socioeconomic impacts of pilot activities on rural livelihood before commencing of National REDD-plus programs to get effective participation of local community in those programs. There is a lack of empirical information or successful model to show that any development policy can really contribute to existing livelihood development of rural community generally in Myanmar and especially in Bago Yoma. Further, policy makers in Myanmar lack of information on means to secure sustainable rural development. Thus, the objective of the study is to provide policy makers with information that may help them in the formulation of more effective REDD-plus policy to contribute to the sustainable rural development through exploring interrelationship between the combinations of livelihood resources and the choice of livelihood strategies of the rural community of the study area.

\section{Objective of the study}

The general objective of the study is to access the socioeconomic impacts of two townships, namely "Yadashae and Oaktwin", both of which are in the area of REDD-plus pilot project. The study tried to answer the following research questions: (1) what are the main livelihood strategies pursued by the households? And (2) what socioeconomic factors are influencing the choice of the livelihood strategies?

\section{Materials and Methods \\ 3.1 Study Area}

This study was conducted in Taungoo District which is located in Bago Region between the latitude $18^{\circ}$ $15^{\prime}$ to $19^{\circ} 59^{\prime} \mathrm{N}$ and longitude $95^{\circ} 51^{\prime}$ to $96^{\circ} 45^{\prime} \mathrm{E}$, Myanmar. The specific areas of the study were the two townships of Taungoo District, namely Yedashae, and Oaktwin which were included in the area of the project entitled "Capacity Building for Developing REDD- plus Activities in the context of Sustainable Forest Management (2012-2015)" which has been implementing jointly by the forest department of Myanmar and International Tropical Timber Organization (ITTO), Japan. In Yedashe township, two villages as the intervention ones were chosen because REDD-plus pilot activities including REDD-plus demonstration plots, extension programs, educational public talks and organizing livelihood development training were mainly carried out in the township. In Oaktwin township, two villages as the control ones were selected in the regards of there were no REDD-plus activities. 


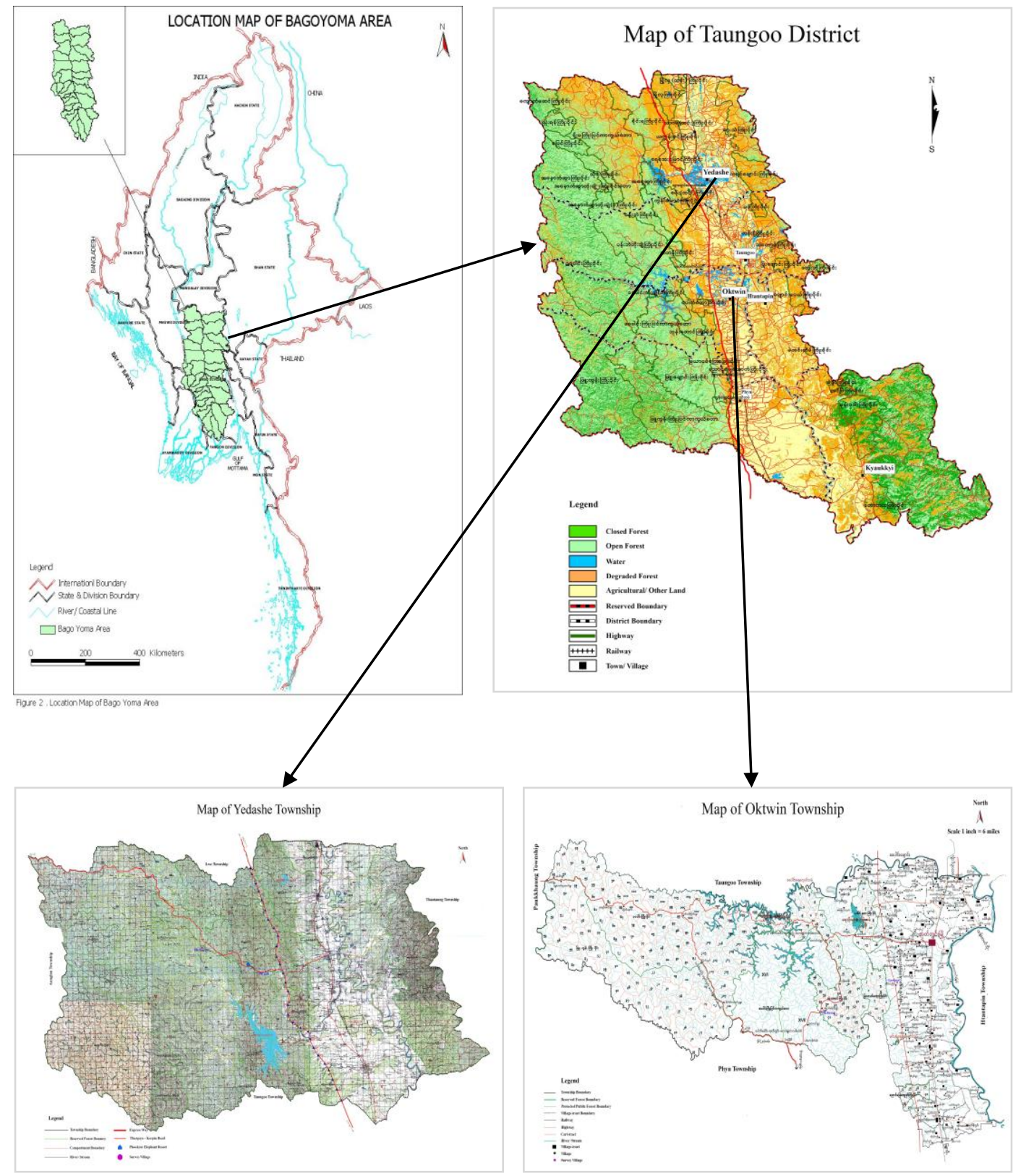

Figure1. Location Map of the Study Area

\subsection{Selection of Sample villages}

Preliminary survey with structured questionnaires was conducted in 16 villages within the two townships. Weighted Average Index (WAI) was applied to access the villages based on the developed eight variables; namely 1) number of households 2) percentage of household with forestry livelihood 3) distance from the main road 4) numbers of community groups 5) strength of forest tenure 6) percentage of village nearby forest 7) NGO intervention 8) reasons for deforestation. The weights are the variance-covariance matrix of that variables and the noisiest variable gets the least weight. Sampling survey villages were chosen based on the nearest weighted average index of the preliminary assessment. The weights were classified into eight scales according to the results from the variance-covariance matrix in which "NGO intervention" and "strength of forest tenure" got the high weight scale of 0.88 and "percentage of village nearby forest" got the least weight of 0.13 . Based on the results of preliminary assessment, two intervention villages, namely 10 mile, Hlae Pywae Gyi and two control villages, Pyaung Gaung and Gawe Gone were respectively chosen to collect all primary data.

Simple random sampling was used for the selection of households. Household survey was carried out in $30 \%$ of total households of each village and the 
primary data was collected through face to face interviews with the household respondents. The survey was conducted using a developed questionnaire to cover required information from respondents. Socioeconomic conditions of the households such as household size, land holding, forest resource use information, household expenditures, household income and their involvement in the REDD-plus pilot activities or forestry related activities, etc. were collected for primary data. The survey questionnaires were identified by using the concepts of Technical Guide Line for Global Comparative Study on REDD-plus published by CIFOR in 2010

In addition to primary data, secondary data related to the study were collected from Forest Department (FD), Township Forest Department, Ministry of Environmental Conservation and Forestry (MOECAF) and REDD-plus project office of Myanmar.

Table 1. Sample households of the four villages

\begin{tabular}{|l|l|l|l|l|}
\hline No. & Township & Village & Total Households & Sampling Households \\
\hline \multirow{2}{*}{1.} & \multirow{2}{*}{ Yedashae } & Hlae Pywae Gyi & 130 & 39 \\
\cline { 3 - 5 } & & 10 mile & 54 & 16 \\
\hline \multirow{2}{*}{2.} & \multirow{2}{*}{ Oaktwin } & Gywae Gone & 49 & 15 \\
\cline { 3 - 5 } & Pyaung Gaung & 83 & 25 \\
\hline \multicolumn{2}{|l}{ Total Sampling Households } & $\mathbf{9 5}$ \\
\hline
\end{tabular}

\subsection{Determining Livelihood Strategies}

In order to access the socioeconomic outcomes and impacts, Hegde (2010) used household surveys and Calderon Angeleri (2005) applied sustainable livelihood framework and asset pentagons. Moreover, Jindal (2010) used before and after control impact (BACI) design and Hedge (2010) used control intervention design, comparing households at control and intervention sites after project implementation. This study used control intervention design parallel to that Hedge (2010) and GCS-REDD and it was based on IDS sustainable livelihoods framework. Institute of Development Studies (IDS, 1998) developed sustainable livelihoods framework which described that given a particular context (of policy setting or socioeconomic conditions), combination of livelihood strategies are resulted through the combination of livelihood resources (different types of capitals). However, the framework emphasized the institutional processes which mediate the ability to carry out such strategies and achieve the sustainable outcomes (Ian, 1998). Chambers and Conway (1992) defined that livelihood comprises the capabilities, assets (including both material and social resources) and activities required for a means of living and sustainable livelihood means when it can cope with and recover from stress and shocks, maintain or enhance its capabilities and assets while not undermining the natural resource base. They also mentioned that pursuing the different livelihood strategies is dependent on the personal capabilities, tangible assets (e.g. stores and material resources) and intangible assets (claims and access). In any investigating of sustainable livelihoods, unraveling and identifying what livelihood resources (or combinations of socioeconomic capitals) are required for different livelihood strategies and it is a key part to be realized in the process of analysis of livelihood development. In this study, K-mean cluster analysis followed by the Principle Component Factor Analysis (PCA) was used for identifying the underlying dimensions that define the correlations among the set of income variables. It can provide clear cut delineation for the categorizing of households into similar livelihood strategies although cluster analysis alone would easily provide more interpreted results and PCA was added because of its usefulness for condensing a large number of variables for obtaining two or three dimensional views of data (Maung and Yamamoto, 2008). Household's Livelihood Strategies (LS) were identified based on the income share of different activities of the households. In this study, all income earning activities of the households were asked through face to face interviews using developed questionnaires and total net income (cash) was used. The exchange rate of Myanmar Union Central Bank on December 2015 was that 1 US \$ was equivalent to 1,300 Kyats and incomes are accounted by Myanmar currency (Kyats) in this study. The period of income accounting for each household was one year. The household income accounting follows the total value of outputs minus the total value of all purchased inputs for each activity i.e. the standard economic definition of income (A. Soltani et al., 2012). Factor analysis was used to study the pattern of relationship among many dependent variables while simultaneously discovering the nature of independent variables that affect them. Clustering households into household categories with similar livelihood strategies can provide useful information for policy makers for better management of policies for livelihood development (De-Janvry and Sadoulet, 2001). The factor loading from PCA is used as the inputs of $\mathrm{K}$-means cluster analysis to reduce misclassification between clusters (Hair et al., 2011). 


\subsection{Determining Livelihood Resources Choice}

To reduce the numbers of variables to a manageable level and to avoid the multicolinearity problems, factor analysis followed by the cluster analysis was applied to livelihood resources (socioeconomic) variables. Variables clusters were named following the capitals which were based on the sustainable livelihood framework (IDS). Drawing on an economic metaphor, IDS's SLF described livelihood resources as the combination of different types of "capital" base from which different productive streams were derived to construct livelihood strategies. There were five "capital" bases namely; natural capital, economic/ financial capital, human capital, social capital and physical capital and so on (Ian Scoones, 1998). In this study, another livelihood resource which is named as "Environmental context" was added based on the study of A. Soltani et al (2012). The livelihoods of households which have access to the five capitals can also be different from the existing geo-climate context of the villages such as weather, forest resource conditions, terrain, etc. After clustering the households into various Livelihood Strategies groups and Livelihood resource choice groups, Multinomial Logit (MNL) Regression was run to know the influence of livelihood resources choice to different livelihood strategies.

Table 2. Livelihood Resources (Socioeconomic Variables)

\begin{tabular}{|c|c|c|}
\hline No. & Livelihood Resources Variables & Identified Clusters \\
\hline $\begin{array}{l}\text { V1. } \\
\text { V2. } \\
\text { V3. } \\
\text { V4. } \\
\text { V5. }\end{array}$ & $\begin{array}{l}\text { Numbers of household (H.H) members } \\
\text { Gender of the respondent } \\
\text { Educational status of household respondent } \\
\text { Household adult members } \\
\text { Age of household head }\end{array}$ & Human Capital \\
\hline V6. & Annual saving & Financial Capital \\
\hline $\begin{array}{l}\text { V7. } \\
\text { V8. } \\
\text { V9. }\end{array}$ & $\begin{array}{l}\text { House conditions } \\
\text { Numbers of properties owned } \\
\text { Vehicle used for transportation } \\
\end{array}$ & Physical Capital \\
\hline $\begin{array}{l}\text { V10. } \\
\text { V11. } \\
\text { V12. } \\
\text { V13. }\end{array}$ & $\begin{array}{l}\text { Fuel wood harvested per year } \\
\text { Bamboo harvested per year } \\
\text { Pole/post harvested per year } \\
\text { Charcoal production per year }\end{array}$ & $\begin{array}{l}\text { Forest Resources } \\
\text { (Natural Capital) }\end{array}$ \\
\hline $\begin{array}{l}\text { V14. } \\
\text { V15. } \\
\text { V16. }\end{array}$ & $\begin{array}{l}\text { Residential land size } \\
\text { Upland size } \\
\text { Lowland size }\end{array}$ & $\begin{array}{l}\text { Land Capital } \\
\text { Capital) }\end{array}$ \\
\hline $\begin{array}{l}\text { V17. } \\
\text { V18. } \\
\text { V19. } \\
\text { V20. }\end{array}$ & $\begin{array}{l}\text { Availability of forest resources } \\
\text { Importance of forest resources on livelihood } \\
\text { Main source of water } \\
\text { Energy for cooking }\end{array}$ & $\begin{array}{l}\text { Forest Resource } \\
\text { (Natural Capital) }\end{array}$ \\
\hline $\begin{array}{l}\text { V21. } \\
\text { V22. } \\
\text { V23. } \\
\text { V24. } \\
\text { V25. }\end{array}$ & $\begin{array}{l}\text { Number of household members participation in forestry related programs } \\
\text { Ethnic group members in household } \\
\text { Numbers of village groups in which household members joined } \\
\text { Numbers of training received } \\
\text { Numbers of public talks received }\end{array}$ & Social Capital \\
\hline $\begin{array}{l}\text { V26. } \\
\text { V27. } \\
\text { V28. }\end{array}$ & $\begin{array}{l}\text { Effect of forestry activities on village's weather } \\
\text { Resource situation within } 2 \text { years } \\
\text { Reason for change of resource situation }\end{array}$ & Environmental context \\
\hline
\end{tabular}

\section{Data Analysis}

Analysis of the collected data were done using Microsoft Excel 2010 and SPSS version 18 for Windows. Descriptive statistics (means, standard deviation and ANOVA, etc.), principle component analysis, cluster analysis and multinomial logit regression were used to explore and compare the livelihood strategies and livelihood resources choice of the two townships.

5. Results

5.1 Analysis on Intervention Villages of Yedashae Township

5.1.1 Main Livelihood Strategies

Livelihood strategies were identified through factor and cluster analysis. The results of Principle Component Analysis (PCA) were presented in Table 3 and Table 4. Determinant value 0.310 showed that there is correlation among the income variables and Direct Oblimin rotation was used in the analysis so as to avoid the multicollinearity and perfect linearity problems. 
Exploring Socioeconomic Impacts of REDD-plus Pilot Program to Rural Livelihoods: Comparative Study of Yedashae and Oaktwin Townships in Bago Region of Myanmar

Table 3. Extracted factors and correlation with original variables used in factor analysis

\begin{tabular}{|l|l|l|l|l|}
\hline \multirow{2}{*}{} & \multicolumn{4}{l|}{ Component } \\
\cline { 2 - 5 } \multicolumn{1}{c|}{} & 1 & 2 & 3 & 4 \\
\hline Agriculture & .856 & .120 & .062 & -.005 \\
Forests & -.443 & -.706 & -.115 & -.235 \\
(NTFPs) & & & & \\
Livestock & .812 & -.004 & .073 & .105 \\
Daily labor & -.645 & .415 & .201 & .090 \\
Wage labor & .033 & .261 & .744 & -.468 \\
Remittance & -.276 & .346 & .144 & .694 \\
Trade & .068 & .530 & -.666 & -.201 \\
Business & .202 & -.463 & .135 & .460 \\
\hline
\end{tabular}

Extraction Method: Principal Component Analysis.

KMO (Kaiser Meyer Olkin criteria) = 0.559;

Bartlett's chi-square $=46.291 ; \mathrm{DF}=28, \mathrm{P}$-value $=$

0.016 , determinant $=0.310$

The cluster analysis based on loading factors presented households into three clusters of Livelihood Strategies (LS) namely; "Forest (NTFPs) and Daily Labor", "Agriculture and Livestock", "Wage Labor" and "Remittance". The four clusters were named according to their characteristics of the significant income share of different activities on each cluster.

Table 4. Final cluster centers with the identified cluster named groups

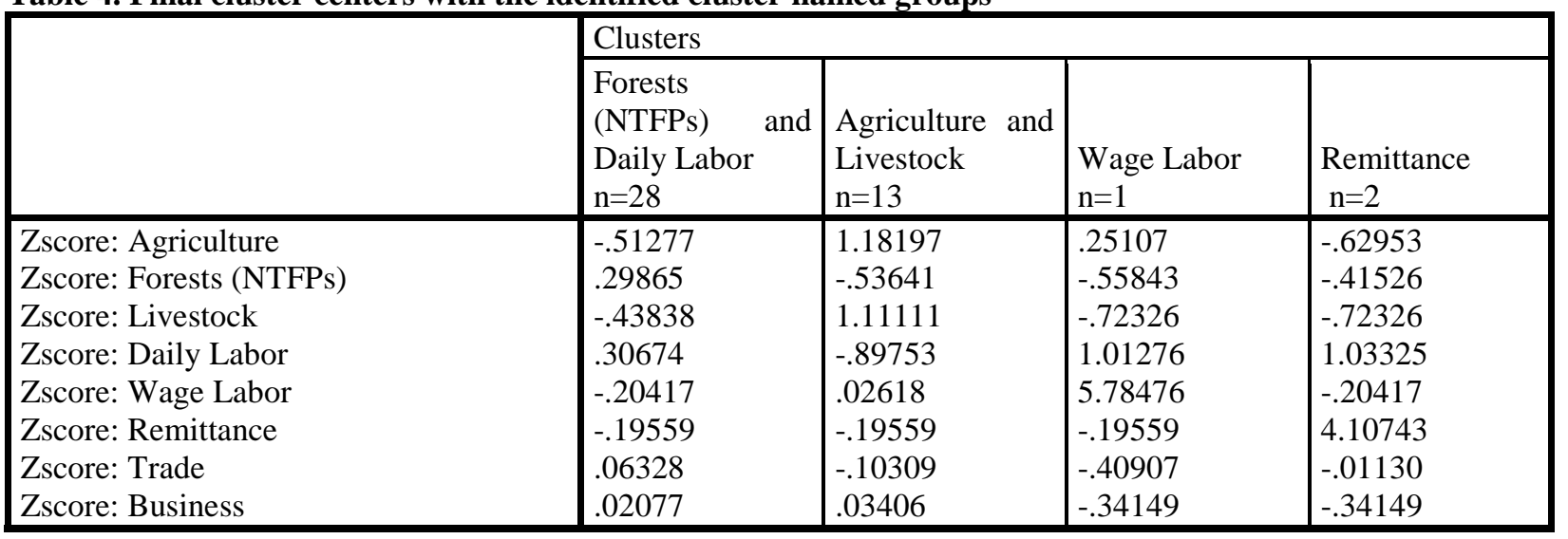

All variables used in the analysis showed statistically significant differences between at least one pair of clusters with the exception of trade and business. Total numbers of household for Yedashae township was 44 and only 1 household fell into $3^{\text {rd }}$ cluster "Wage Labor" and 2 households fell into $4^{\text {th }}$ cluster "Remittance".

Table 5. ANOVA for the four clusters

\begin{tabular}{|c|c|c|c|c|c|c|}
\hline \multirow[b]{2}{*}{ Items } & \multicolumn{2}{|c|}{ Cluster $(n=44)$} & \multicolumn{2}{|l|}{ Error } & \multirow[b]{2}{*}{$\mathrm{F}$} & \multirow[b]{2}{*}{ Sig. } \\
\hline & $\begin{array}{l}\text { Mean } \\
\text { Square }\end{array}$ & df & $\begin{array}{l}\text { Mean } \\
\text { Square }\end{array}$ & df & & \\
\hline Zscore: Agriculture & 8.793 & 3 & .416 & 40 & 21.162 & .000 \\
\hline Zscore: Forests (NTFPs) & 2.298 & 3 & .903 & 40 & 2.546 & .070 \\
\hline Zscore: Livestock & 7.667 & 3 & .500 & 40 & 15.333 & .000 \\
\hline Zscore: Daily Labor & 5.423 & 3 & .668 & 40 & 8.114 & .000 \\
\hline Zscore: Wage Labor & 11.574 & 3 & .207 & 40 & 55.934 & .000 \\
\hline Zscore: Remittance & 11.783 & 3 & .191 & 40 & 61.600 & .000 \\
\hline Zscore: Trade & .139 & 3 & 1.065 & 40 & .131 & .941 \\
\hline Zscore: Business & .126 & 3 & 1.066 & 40 & .118 & .949 \\
\hline
\end{tabular}

5.1.2 Main Livelihood Resources Choices

There are 28 socioeconomic variables (Table 2) for each township which are correlated with each other and it was required to reduce to a manageable level. The results of cluster analysis on the livelihood resource variables are presented in Table 6. These clusters were grouped based on the sustainable livelihoods capitals and labeled 
Exploring Socioeconomic Impacts of REDD-plus Pilot Program to Rural Livelihoods: Comparative Study of Yedashae and Oaktwin Townships in Bago Region of Myanmar

according to correlation and sign with the original variables.

Table 6. Cluster analysis for livelihood resource variables

\begin{tabular}{|c|c|c|c|}
\hline \multirow{2}{*}{$\begin{array}{l}\text { Clusters } \\
\text { (Combination of Livelihood } \\
\text { Resources) }\end{array}$} & \multicolumn{2}{|c|}{ Correlation with Original Livelihood Resource Variables } & \multirow[t]{2}{*}{$\begin{array}{l}\text { No. of } \\
\text { Households (n) }\end{array}$} \\
\hline & Positive & Negative & \\
\hline $\begin{array}{l}\text { NTFPs, Social and Physical } \\
\text { Capitals }\end{array}$ & $\begin{array}{l}\text { Pole/post harvested per year } \\
\text { No. training received } \\
\text { Bamboo harvested per year } \\
\text { Availability of free forest resources } \\
\text { Conditions of house } \\
\text { Annual saving }\end{array}$ & $\begin{array}{l}\text { No. of public talk received } \\
\text { Source of water } \\
\text { Importance of forest resources on } \\
\text { Livelihood } \\
\text { No. of properties owned }\end{array}$ & 2 \\
\hline
\end{tabular}

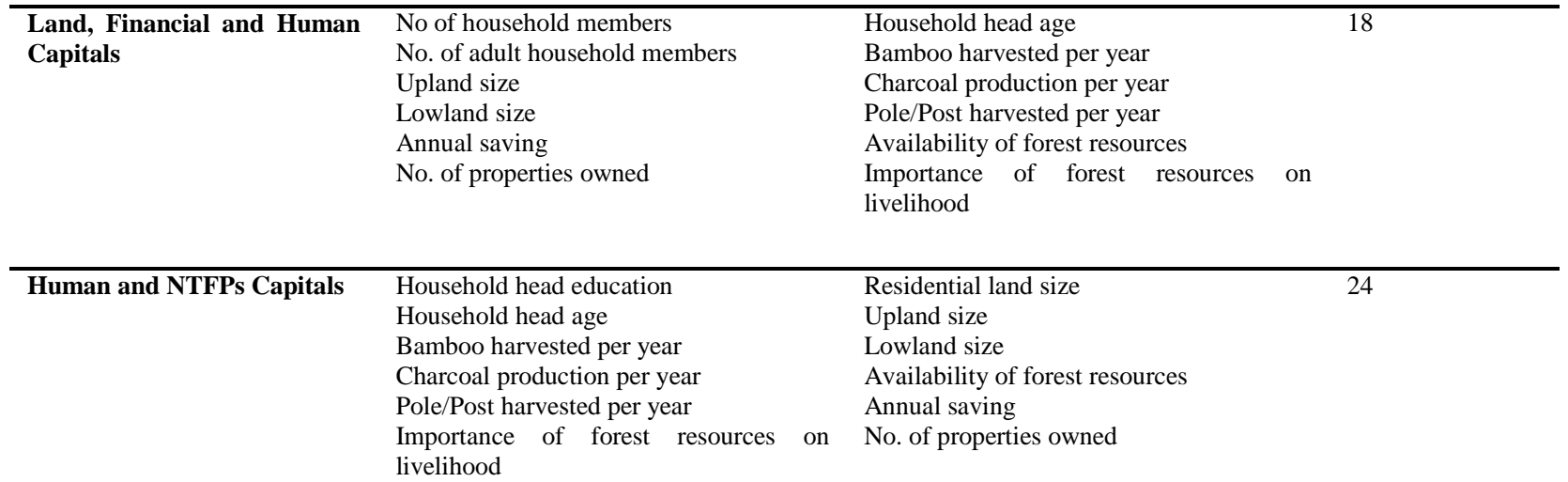

Note: Only loading above 0.3 are displayed

5.1.3 Livelihood Resource Factors Influencing Choice of Livelihood Strategies

Multinomial logit regression was run to know the effect of each explanatory variable (livelihood resource variables) on the choice of livelihood strategies (LS) through determining the "Remittance" LS as the reference category. Table 7 describes the determinants of livelihood strategies of two intervention villages.

Table 7. Determinant of livelihood Strategies (Multinomial Logit Regression)

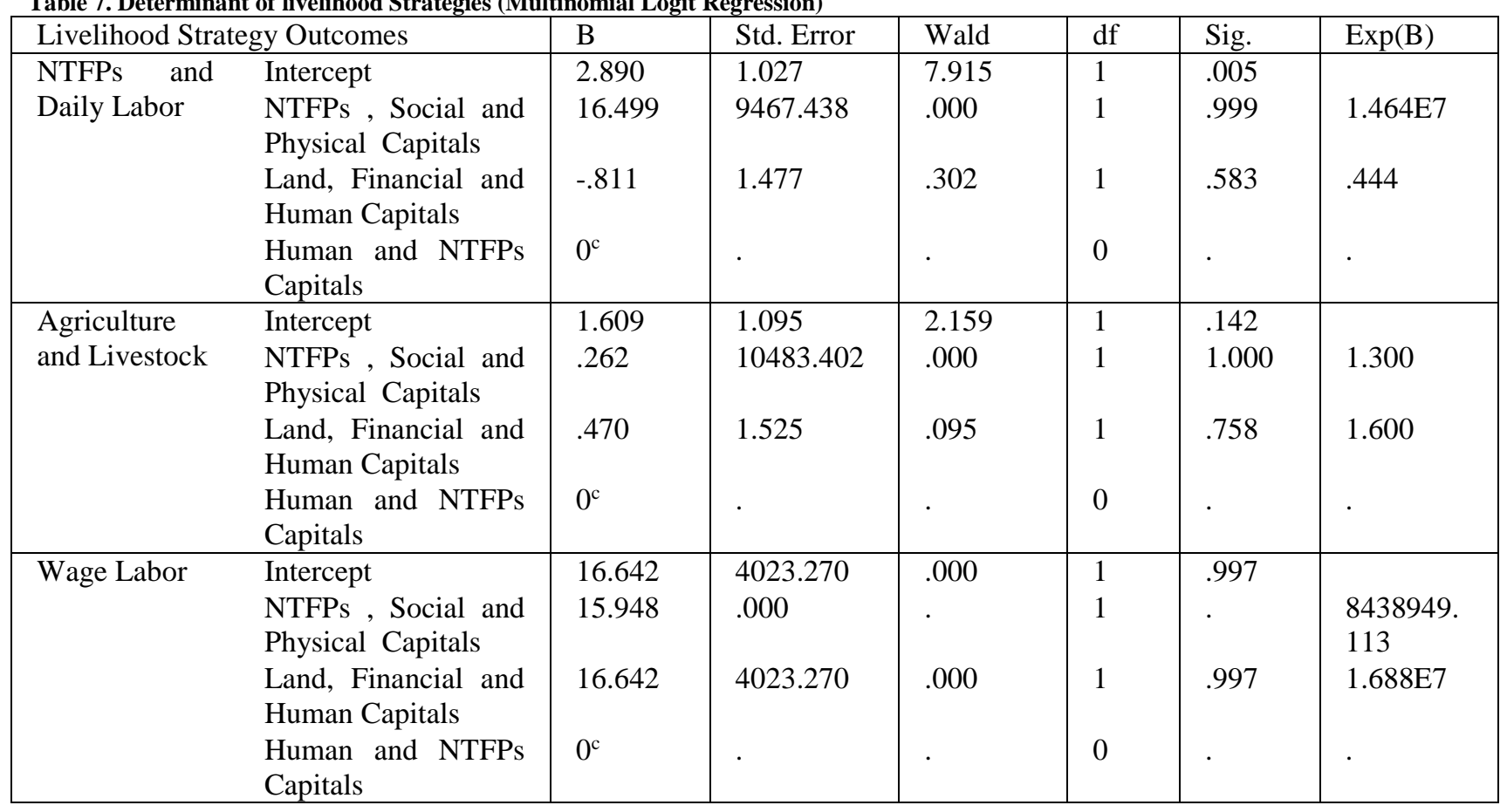


Exploring Socioeconomic Impacts of REDD-plus Pilot Program to Rural Livelihoods: Comparative Study of Yedashae and Oaktwin Townships in Bago Region of Myanmar

Pseudo R-square: McFadden = 0.91; Nagelkerke =0.179; Cox and Snell =0.148.

Chi-square $=7.039 ; \mathrm{df}=6 ; \mathrm{p}$-value $=0.318($ Significant at $5 \%)$

The reference category is "Remittance".

5.2 Analysis on Control Villages of Oaktwin Township

5.2.1 Main Livelihood Strategies

In the two villages for control villages, K-mean cluster analysis followed by the principle component analysis (PCA) was also used to identify the different livelihood strategies (LS) groups. The results were presented in Table 8 and Table 9. PCA loaded 4 components, in which the eigenvalues is greater than 1 , as the principle components but $\mathrm{k}$ means cluster analysis was followed to get the best components which can explain most of the overall variance in the observed variables.

Table 8. Extracted factors and correlation with original variables used in factor analysis

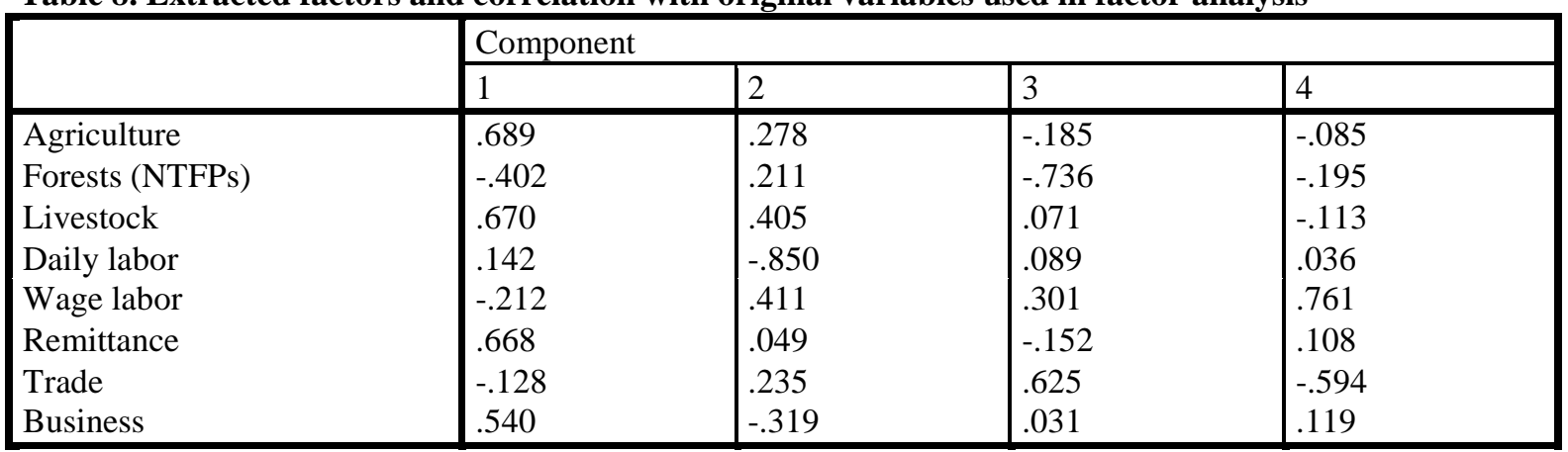

Extraction Method: Principal Component Analysis.

KMO (Kaiser Meyer Olkin criteria) $=0.532$; Bartlett's chi-square=31.196; DF=28, P-value=0.308, determinant $=0.480$

Four clusters were identified based on the 4 components from factor analysis. Compare to those results of cluster analysis of 3-cluster and 4-cluster, all variables used in the analysis showed statistically significant impact on all the clusters with the exception of trade in 3-cluster. While in 4-cluster identification, Forests (NTFPs), Livestock and Business do not have a significant impact on determining which clusters was grouped into. In the cluster analysis for the control villages, 3-cluster identification was chosen as the main livelihood strategies clusters which were different from the factor loading of PCA.

Table 9. Final cluster centers with the identified cluster named groups

\begin{tabular}{|l|l|l|l|}
\hline \multicolumn{3}{|l|}{} & \multicolumn{3}{|l|}{\begin{tabular}{l} 
Cluster \\
\cline { 2 - 4 }
\end{tabular}} & $\begin{array}{l}\text { Agriculture and } \\
\text { Livestock } \\
\mathrm{n}=6\end{array}$ & $\begin{array}{l}\text { NTFPs and Wage } \\
\text { Labor } \\
\mathrm{n}=13\end{array}$ & $\begin{array}{l}\text { Daily } \\
\text { Trade } \\
\mathrm{n}=28\end{array}$ \\
\hline Zscore: Agriculture & 1.83586 & -.15597 & -.32098 \\
Zscore: Forests (NTFPs) & -.46113 & 1.02671 & -.37787 \\
Zscore: Livestock & 1.86050 & -.34593 & -.23807 \\
Zscore: Daily labor & -.35683 & -.77988 & .43855 \\
Zscore: Wage labor & -.20527 & .53685 & -.20527 \\
Zscore: Remittance & 1.42313 & -.20826 & -.20826 \\
Zscore: Trade & -.24280 & -.11342 & .10469 \\
Zscore: Business & .35534 & -.40658 & .11262 \\
\hline
\end{tabular}

The three clusters were named according to their highest loading of the income share of different activities on each cluster and they could explain the relationship of each variable to the underlying cluster. The first cluster was named "Agriculture and Livestock", the second cluster was named "Forests (NTFPs) and Wage Labor" and the third one was named "Daily Labor and Trade". The mean square value of each variables and p-value of each variables for the three clusters are presented in the table below. 
Exploring Socioeconomic Impacts of REDD-plus Pilot Program to Rural Livelihoods: Comparative Study of Yedashae and Oaktwin Townships in Bago Region of Myanmar

Table 10. ANOVA for the three clusters

\begin{tabular}{|l|l|l|l|l|l|l|}
\hline & \multicolumn{2}{l|}{ Cluster (n=47) } & \multicolumn{2}{l|}{ Error } & \multirow{2}{*}{ F } & Sig. \\
\cline { 2 - 5 } & $\begin{array}{l}\text { Mean } \\
\text { Square }\end{array}$ & df & $\begin{array}{l}\text { Mean } \\
\text { Square }\end{array}$ & df & & \\
\hline Zscore: Agriculture & 11.712 & 2 & .513 & 44 & 22.825 & .000 \\
Zscore: Forests (NTFPs) & 9.489 & 2 & .614 & 44 & 15.450 & .000 \\
Zscore: Livestock & 11.956 & 2 & .502 & 44 & 23.815 & .000 \\
Zscore: Daily labor & 7.028 & 2 & .726 & 44 & 9.680 & .000 \\
Zscore: Wage labor & 2.590 & 2 & .928 & 44 & 2.791 & .072 \\
Zscore: Remittance & 6.965 & 2 & .729 & 44 & 9.556 & .000 \\
Zscore: Trade & .414 & 2 & 1.027 & 44 & .403 & .671 \\
Zscore: Business & 1.631 & 2 & .971 & 44 & 1.679 & .198 \\
\hline
\end{tabular}

5.2.2 Main Livelihood Resources Choices

The result of factor analysis for livelihood resource variables showed five significant clusters. These clusters were labeled according to correlation with the original livelihood resource variables (Table 11).

Table 11. Cluster analysis for livelihood resource variables

\begin{tabular}{|c|c|c|c|}
\hline \multirow{2}{*}{$\begin{array}{l}\text { Clusters } \\
\text { (Combination of } \\
\text { Livelihood Resources) }\end{array}$} & \multicolumn{2}{|c|}{ Correlation with Original Livelihood Resource Variables } & \multirow{2}{*}{$\begin{array}{l}\text { No. of } \\
\text { Households } \\
\text { (n) }\end{array}$} \\
\hline & Positive & Negative & \\
\hline $\begin{array}{l}\text { Land and Human } \\
\text { Capitals }\end{array}$ & $\begin{array}{l}\text { Residential land size } \\
\text { Lowland size } \\
\text { Upland size } \\
\text { No. of household adult member } \\
\text { No. of properties owned }\end{array}$ & $\begin{array}{l}\text { No. of training received } \\
\text { Fuel wood harvested per year } \\
\text { Pole/Post harvested per year } \\
\text { Bamboo harvested per year } \\
\text { Annual saving }\end{array}$ & 1 \\
\hline $\begin{array}{l}\text { Forest Resource and } \\
\text { Physical Capitals }\end{array}$ & $\begin{array}{l}\text { Pole/Post harvested per year } \\
\text { Charcoal production per year } \\
\text { Main source of water } \\
\text { House condition } \\
\text { No. of assets owned }\end{array}$ & $\begin{array}{l}\text { Household head age } \\
\text { No. of household members } \\
\text { Residential land size } \\
\text { Lowland size } \\
\text { Annual saving } \\
\text { No. of village group membership }\end{array}$ & 4 \\
\hline $\begin{array}{l}\text { Financial and Natural } \\
\text { (Land and Forest } \\
\text { Resource) Capitals }\end{array}$ & $\begin{array}{l}\text { Pole/Post harvested per year } \\
\text { Fuel wood harvested per year } \\
\text { Residential land size } \\
\text { Lowland size } \\
\text { Annual saving } \\
\text { Availability of resources } \\
\text { Importance of forest resources }\end{array}$ & $\begin{array}{l}\text { Gender of the H.H head } \\
\text { No. of public talk received }\end{array}$ & 12 \\
\hline $\begin{array}{lr}\text { Social and } & \text { Forest } \\
\text { Resource } & \text { Capitals } \\
\text { (Taungya) } & \end{array}$ & $\begin{array}{l}\text { Charcoal production per year } \\
\text { Bamboo harvested per year } \\
\text { H.H ethnic membership } \\
\text { No. of H.H member participation } \\
\text { in forestry programs } \\
\text { Upland size }\end{array}$ & $\begin{array}{l}\text { No. of H.H members } \\
\text { Lowland size } \\
\text { Residential land size } \\
\text { Annual saving }\end{array}$ & 15 \\
\hline $\begin{array}{l}\text { Environmental State } \\
\text { and Forest Resource } \\
\text { Capitals }\end{array}$ & $\begin{array}{l}\text { Fuel wood harvested per year } \\
\text { Importance of forest resources } \\
\text { Resource situation within } 2 \text { years } \\
\text { Effect of forestry activities on } \\
\text { village weather }\end{array}$ & $\begin{array}{l}\text { H.H adult member } \\
\text { No. of training received } \\
\text { Bamboo harvested per year } \\
\text { Charcoal production per year } \\
\text { Annual saving }\end{array}$ & 15 \\
\hline
\end{tabular}

Note: Only loading above 0.2 are displayed

\subsubsection{Livelihood Resource Factors Influencing Choice of Livelihood Strategies}

The likelihood of the particular Livelihood Strategies (LS) choice which depends on the different combination of livelihood resource variables are explained through multinomial regression relative to the reference category as "Daily Labor and Trade". The results are presented in Table 12. 
Exploring Socioeconomic Impacts of REDD-plus Pilot Program to Rural Livelihoods: Comparative Study of Yedashae and Oaktwin Townships in Bago Region of Myanmar

Table 12. Determinant of livelihood strategies (Multinomial Logit Regression)

\begin{tabular}{|c|c|c|c|c|c|c|c|}
\hline \multicolumn{2}{|c|}{ Livelihood Strategy Outcomes } & $\mathrm{B}$ & Std. Error & Wald & $\mathrm{df}$ & Sig. & $\operatorname{Exp}(B)$ \\
\hline \multirow{10}{*}{$\begin{array}{l}\text { Agriculture } \\
\text { and } \\
\text { Livestock }\end{array}$} & Intercept & -2.565 & 1.038 & 6.109 & 1 & .013 & \\
\hline & Land and Human & 20.862 & 7769.025 & .000 & 1 & .998 & $1.149 \mathrm{E} 9$ \\
\hline & Capitals & & & & & & \\
\hline & Forest Resource and & -11.790 & 1309.710 & .000 & 1 & .993 & $7.579 \mathrm{E}-6$ \\
\hline & Physical Capitals & & & & & & \\
\hline & Financial and Natural & 2.159 & 1.222 & 3.122 & 1 & .077 & 8.667 \\
\hline & $\begin{array}{l}\text { (Land and Forest } \\
\text { Resource) Capitals }\end{array}$ & & & & & & \\
\hline & Social and Forest & -12.018 & 518.970 & .001 & 1 & .982 & $6.034 \mathrm{E}-6$ \\
\hline & $\begin{array}{l}\text { Resource } \\
\text { (Taungya) }\end{array}$ & & & & & & \\
\hline & $\begin{array}{l}\text { Environmental State } \\
\text { and Forest Resource } \\
\text { Capitals }\end{array}$ & $0^{\mathrm{c}}$ & . & . & 0 & . & . \\
\hline \multirow{7}{*}{$\begin{array}{l}\text { NTFPs and } \\
\text { Wage Labor }\end{array}$} & Intercept & -2.565 & 1.038 & 6.109 & 1 & .013 & \\
\hline & $\begin{array}{l}\text { Land and Human } \\
\text { Capitals }\end{array}$ & 1.798 & .000 & & 1 & . & 6.036 \\
\hline & $\begin{array}{l}\text { Forest Resource and } \\
\text { Physical Capitals }\end{array}$ & 3.664 & 1.553 & 5.569 & 1 & .018 & 39.000 \\
\hline & $\begin{array}{l}\text { Financial and Natural } \\
\text { (Land and Forest } \\
\text { Resource) Capitals }\end{array}$ & 1.466 & 1.320 & 1.233 & 1 & .267 & 4.333 \\
\hline & Social and Forest & 2.431 & 1.160 & 4.396 & 1 & .036 & 11.375 \\
\hline & $\begin{array}{l}\text { Resource } \\
\text { (Taungya) }\end{array}$ & & & & & & \\
\hline & $\begin{array}{l}\text { Environmental State } \\
\text { and Forest Resource } \\
\text { Capitals }\end{array}$ & $0^{c}$ & . & . & 0 & & \\
\hline
\end{tabular}

Pseudo R-square: McFadden $=0.265 ;$ Nagelkerke $=0.460 ;$ Cox and Snell $=0.388$.

Chi-square $=23.068 ; \mathrm{df}=8 ; \mathrm{p}$-value $=0.003$ (Significant at $5 \%$ )

The reference category is "Daily Labor and Trade".

\section{Discussion}

\subsection{Main Livelihood Strategies and Resources Combination for Intervention Villages}

Households in the intervention villages followed three different Livelihood Strategies (LS) namely; Forest and Daily Labor, Agriculture and Livestock, Wage Labor and Remittance. Households pursing the first LS (Forest and Daily Labor) were relatively dependent on the access on natural forest resources such as bamboo, charcoal and firewood etc. and were characterized by the lack of land assets. About $63 \%$ of sample households of two villages relatively followed "Forest and Daily Labor" LS while about $29 \%$ of sample households pursued "Agriculture and Livestock" LS. All the income shares of different activities expect from trade and business are significant impact on all the cluster loadings. Based on the Livelihood Strategies cluster analysis, forests (NTFPs) income and daily labor income is relatively significant income source of LS of all sample households for intervention villages. That LS dominates in accessibility (transportation) and land possession for cultivation of commercial crops is not feasible.
To follow the abovementioned particular LS, households need to possess or access to certain livelihood resource or a combination of livelihood resources. In Yedashae township, three combinations of livelihood resource choices can be pointed out to pursue the particular livelihood strategy (LS). The $1^{\text {st }}$ livelihood resources cluster was named as "Forest, Social and Physical Capitals", the $2^{\text {nd }}$ was as "Land, Financial and Human Capitals" and the $3^{\text {rd }}$ one was as "Forest and Human Capitals". In this study, we divided natural capital into two types; Forest (NTFPs) and Land Capitals. About 55\% of sample households could have access to "NTFPs and Human Capitals". It means that they relatively pursued Daily Labor and Forest Livelihood Strategies (LS) compared to other households with Land, Financial and Human Capitals. The study found that NTFPs capital is included in common in the $1^{\text {st }}$ and the $3^{\text {rd }}$ livelihood resource choice clusters, only $4 \%$ of sample households fall into the $1^{\text {st }}$ cluster of NTFPS, Social and Physical Capitals. It can be explained that those households depend mainly on natural resources for their subsistence use which is different from the 
$3^{\text {rd }}$ resource choice of "NTFPs and Human Capitals" in which the income stream was from the dependence of "NTFPs". Annual saving (livelihood resource) variable is highest and had positive correlation with the first livelihood resources choice "NTFPS, Social and Physical Capitals" but the negative correlation with the $3^{\text {rd }}$ resource choice "NTFPs and Human Capitals". It showed that the households in the intervention villages which depended on natural resources did not have enough income for their livelihood compared to those who have land resources and physical resources. "Importance of forest resources" was also positively correlated with the $1^{\text {st }}$ and $3^{\text {rd }}$ resource clusters and negatively with the $2^{\text {nd }}$ cluster and it says that the households which depend on the natural resources for their LS choice accepted that the natural forest resources are of crucial for their subsistence and commercial use.

\subsection{Factors Influencing Choice of Livelihood Strategies}

All the livelihood resource combinations had no significant impact on the choice of particular livelihood strategies choice for all the sample households in the intervention villages. Households with "Land, Financial and Human Capitals" compared to the households with "Human and NTFPs Capitals" are about $45 \%$ less likely to choose "NTFPs and Daily Labor" LS relative to the "Remittance" LS. Households with "Land, Financial and Human" resources compared to the households with "Human and NTFPs Capitals" are also about $2 \%$ more likely to choose "Agriculture and Livestock" LS relative to the "Remittance" LS. For the households with the $1^{\text {st }}$ and $2^{\text {nd }}$ livelihood resources, both are more likely to choose wage labor relative to the remittance. From this analysis, we could draw that there is no significant livelihood resource choice for all the livelihood strategies (LS) which are pursuing by the villagers of the intervention villages. Local villagers were needed to depend on both forest and land capital for their livelihood. From the combination of livelihood resource clusters, household with land capital assets have better financial assets rather than the households with forest assets. Drawing on this, depending on the forest resources for livelihood could provide as the temporary livelihood strategies and they had to depend on the human capitals of the households to do the other daily income activities such as daily labor in the other's households' farms or departmental plantations or private plantations etc.

\subsection{Main Livelihood Strategies and Resources Combination for Control Villages}

In control villages in the regard of no REDD-plus activities are introduced, the study found that three different livelihood strategy (LS) clusters. About $12 \%$ sample households fall under the $1^{\text {st }}$ cluster named "Agriculture and Livestock", 27\% of households under the $2^{\text {nd }}$ cluster "NTFPs and Wage Labor" and the rest fall under the last cluster "Daily Labor and Trade". Households pursuing the $1^{\text {st }}$ Livelihood Strategies (LS) were characterized by the lack of access to NTFPs. Income from forest resources (NTFPs) was only significant impact on the $2^{\text {nd }}$ cluster "NTFPs and Wage Labor". Most of the households in Oaktwin township have relatively been pursuing the $3^{\text {rd }}$ LS "Daily Labor and Trade" compared to the other two remaining household livelihood strategies (LS). The "Daily Labor and Trade" LS is influenced by the environmental state of the study areas in Oaktwin township whereas both of two villages are surrounded by farms, departmental plantations and private plantations.

The cluster analysis of 28 livelihood resources for control villages explains five clusters of combination of livelihood resources for sample households (Table 11). The livelihood resource variables, "Household ethnic membership" and "No. of Household member participation in forestry programs", had the high loading and positively correlated with the "Social and Forest Resource Capital" and it explains that some households in control villages have ethnic households (Karen Ethnic people) and their main livelihood strategy highly relied on the forest resource capital. Most of the households which have access to those resource capitals rely on working in "Taungya" system. Taungya is a Myanmar word and its meaning is upland field or upland farming together growing with the teak seedlings especially in Departmental Special Teak Plantations of Bago Yoma (Maung and Yamamot, 2008). Based on the cluster loading, forest resource capitals can be found in combination with the physical resources and environmental context resources. It can be highlighted that households with "Forest Resource and Physical Capital" had to depend on forest resources for their commercial use which were characterized with the positive correlation with "charcoal production per year" and negative correlation with all the land resources. On the other hand, households' capitals together with "Forest and Environmental Context Capitals" had to depend on forest resources for their subsistence use because of the negative correlation with the extraction of charcoal and bamboo and positive correlation with lowland size.

\subsection{Factors Influencing Choice of Livelihood Strategies}

The importance of natural resources (both NTFPs and land) as an input for cultivation and financial resources from livestock (especially from pig breeding) explained the positive correlation and had the significant impact on the choice of "Agriculture and Livestock". Households with the "Financial and Natural (Land and Forest resources) Capitals" 
compared with the households with "Environmental Context and Forest Resource Capitals" were about $87 \%$ more likely to pursue "Agriculture and Livestock" relative to "Daily Labor and Trade". Both "Forest Resource and Physical Capital" and "Social and Forest Resource Capital (Taungya)" had the significant impact on the choice of "NTFPs and Wage Labor" LS relative to "Daily Labor and Trade" LS. The "Annual Saving" resource was positively correlated only in "Financial and Natural (Land and Forest Resource) Capitals. The later had significant impact on the choice of "NTFPs and Wage Labor" LS rather than the "Daily Labor and Trade" LS which was used as reference category in this analysis of Oaktwin township. Although all the households which had access to these combinations of specific livelihood resources "Forest Resources and Physical Capitals, Financial and Natural Capitals, Social and Forest Resource Capitals" compared to the households with "Environmental Context and Forest Resource Capitals" are more likely to choose "NTFPs and Wage Labor" LS relative to the reference category, the highest correlated one is the "Forest Resources and Physical Capitals" households. This shows that all the households' livelihood strategies include dependency on forest resources but it solely cannot contribute to the livelihood development of the households.

\subsection{Socioeconomic Impacts of REDD-plus program}

Overall, this study found very limited socioeconomic impacts of REDD-plus pilot project on local communities. There is no significant impact of livelihood resources on livelihood strategies (LS) in intervention villages although almost all of the households are pursuing "Forests (NTFPs) and Wage Labor" LS. Significant impact of livelihood resource combinations on LS pursued especially on "NTFPs and Wage Labor" LS can be found in control villages while most of the households are pursuing "Daily Labor and Trade" LS. Most of the households in intervention villages of Yedashae Township depended on the forest resources (NTFPs) for their livelihoods and they did not have enough income for their welfare. For control villages, households were pursuing daily labor for their livelihood and they also have to depend on forest resources for their subsistence and commercial purposes. The project contributed mainly on the awareness raising especially for the social capital and it had no significant impact on the other capitals in intervention villages. The social capital of ethnic households' participation in forestry related activities in control villages explored standalone livelihood strategy called "Taungya" in Myanmar. People in intervention villages encroached to the reserved forests in the past years. However, Government of Myanmar has been processing landuse policy reform and during a period of 2013-2015, the Ministry of Environmental Conservation and Forestry (MOECAF) had changed legally the land ownership title of above 50 household-encroached villages to gazette village land. And hence, the households in the intervention villages have limited access to permanent agricultural land through shifting cultivation in the reserved forests nearby the village. Therefore, the influence of livelihood resources in the intervention villages was not significant and they had to depend on the combination of livelihood resources alternatively. This study also found that the sole dependency of forest resources for livelihood could not create standalone livelihood strategy in the area of high poverty and forest dependency rate.

\section{Conclusion}

This research has emphasized the identification of pursuing households' livelihood strategies through the access of the existing livelihood resource combination of households both in intervention villages and control villages to know the socioeconomic impacts of REDD-plus pilot program. In particular, REDD-plus socioeconomic impacts can be accessed through the counterfactual scenarios but these methods are challenging in terms of technical, time and economical aspects. An analysis of these household data within the project area aimed to provide insights into policies for re-addressing deforestation through the rural livelihood development with active participation of the community. It cannot be hoped that the pilot program could support to all the livelihood capitals of the intervention villages because of the duration and the nature of the pilot projects. However, the study found that the REDD-plus programs could contribute well to the awareness raising of the rural people in intervention villages. Khaine et al (2014) also found that the environmental knowledge of villages in Yedashae township is higher than those in Oaktwin township. All the villages in the study area could be mentioned that most of the households are poor and also, forest dependency for subsistence and commercial use is relatively high compared to other income generating activities. Integrated household living condition assessment project technical unit (2011) also reported that rural poverty contributes to $84 \%$ of total poverty of Myanmar and rural people depend on the forests for their livelihood (FD, 2014). To sum up the study, households' livelihood strategies are followed through the extraction of forest resources combining with other livelihood resources especially human resources and there are low opportunities for other income generating activities. In a condition of poverty, if policies would not support people's livelihood strategies to be more sustainable and effective, poor people may be forced for their survival by means of continuous relying on the short-term over-exploitation of natural resources. 
This study suggests the policy makers to pay more attention to put a channel for creating other income generating activities together with the REDD-plus programs in order to get awareness and participation of REDD-plus programs. All the households from the study area knew very well that all the forestry activities could create temporary income or job for their livelihood. Kathleen et al., (2010) also described that case study evidences suggest a few policy options for ensuring meaningful citizen participation in land reforms, but more rigorous analyses of these policies produce participation and whether this participation leads to positive welfare outcomes is needed. It is quite challenging task for policy makers or project proponent to show or to prove that the long-term forest conservation programs have benefits not only on the environment but also on the community livelihood development. K. Lawlor et al., (2010) suggested that rural people require secure tenure, economic incentives for conservation, and the opportunity to participate in program design and implementation. This study suggests as Community Forestry (CF) as a potential way for the integration into REDD-plus programs. The existing policy and legislative frameworks for $\mathrm{CF}$ could be alternatively viewed as supportive conduits for community development. Moreover, inter-sectoral dialogue for the cooperation among agencies and line-departments should be enhanced to ensure that implementing REDD-plus programs benefits to local communities' livelihood resources.

\section{Acknowledgement}

I would like to express my sincere thanks to APFNet (Asia Pacific Network for Sustainable Forest Management and Rehabilitation) for providing me a scholarship to study at Beijing Forestry University. I would like to express my deepest gratitude to my coauthors, Professor Dr. WEN Yali, Associate Dean of School of Forest Economic and Management, Beijing Forestry University and Mr. Zaw Zaw, Staff Officer, Forest Research Institute, for their great support to carry out this study. My deepest appreciation also goes to Ministry of Environmental Conservation and Forestry (MOECAF), for giving me a permission to study abroad.

\section{References}

1) Anna C. and Smita N., 2011, Climate Change Policy Brief: REDD-plus Finance Delivery: Lessons from Early Experiences.

2) Arezoo S. et al., 2012, Poverty, Sustainability and Household Livelihood Strategies in Zagros, Iran.

3) Calderon A., 2005, Livelihood impact assessment: Noel Kempff Mercado Climate Action Project, Bolivia, November. Annex 6 of project design document.

4) Cecilia L., Lasse L., Maria F. G., Demetrius K., Maria B., Arild A. and William D. S, 2012, Who should benefit from REDD+?: Rationales and Realities.

5) Chambers, R. and Conway G., 1991. Sustainable rural livelihoods: Practical concepts for the $21^{\text {st }}$ Century. IDS
Discussion Paper No.296. Sussex, UK: Institute of Development Studies.

6) De-Janvy, A. and Sadoulet, E., 2001, Income Strategies among rural households in Mexico: The role of off-farm activities.

7) Esteve C., Katrina B. and Neil W. A, 2007, The Equity and Legitimacy of Markets for Ecosystem Services.

8) Framework Convention on Climate Change, 2010, Report of the Conference of the Parties on its sixteenth session, Cancun

9) Groom, B., Grosjean, P., Kontoleon, A., Swanson, T. and Zhang, S., 2010. Relaxing constraints with compensation: a win-win policy for environment and poverty in China? Oxford Econ. Pap. 62, 132-156.

10) Groom. B. and Palmer. C., 2012, REDD+ and Rural Livelihood: REDD+ and Conservation.

11) Hedge, R., 2010. Payments for Ecosystem Services and farm household behavior: the case of carbon in Mozambique's agroforests.

12) Integrated household living condition assessment project technical unit of Myanmar (IHLCA), 2011. Integrated household living conditions survey in Myanmar: Poverty profile, Yangon (Myanmar): United Nation Development Programme.

13) Jindal, R., 2010. Livelihood impacts of payments for forestry carbon services: Field evidence from Mozambique.

14) Joe F. H., Marko S., Christian M. R. and Jeannette A. M., 2011, An assessment of the use of partial least squares structural equation modeling in marketing research.

15) Karen B., 1999, Implementing a Sustainable Livelihoods Framework for Policy-Directed Research: Reflection from practice in Mali', IDS Working Paper 90.

16) Kathleen L. and Lydia P.O., 2010, Institutions and policies to protect rural livelihoods in REDD regimes.

17) Khaine et al., 2014. Assessment of the environmental awareness of local people living in and around forests in Myanmar: A case study in Yedashae and Pauk-kaung townships.

18) Leo P., and Kimberly T., 2012, Putting REDD+ safeguards and safeguard information systems into practice, UN-REDD PolicyBrief Issue \#03 10.1007/s10531-014-0821-4.

19) Margaret S., Cecilia S., Alejandro V., and Jose' C. F., 2013 Rights to carbon and payments for services rendered under REDD+: Options for the case of Mexico, Global Environmental Change 23 (2013) 813-825.

20) Maung.T. M. and Yamamoto. M., 2008, Exploring the socioeconomic situation of plantation villagers: A case study in Myanmar Bago Yoma.

21) Ministry of Environmental Conservation and Forestry, 2014. Forestry in Myanmar: Forest Department.

22) Pamela J., Maria B., Amy E. D., Maria F.G., Kathleen L., Ida A. P. R. and William D. S., Multi-Level policy dialogues, processes, and actions: Challenges and opportunities for National REDD+ safeguards Measurement, Reporting, and Verification (MRV), Forests 2014, 5, 2136-2162; doi:10.3390/f5092136: ISSN 1999-4907.

23) Pascale C. M., Romain P. and Jean-Louis C., 2008, A methodology to estimate impacts of domestic policies on deforestation: Compensated Successful Efforts for "avoided deforestation" (REDD).

24) Scoones. I., 1998, 'Sustainable Rural Livelihoods: A Framework for Analysis' IDS Working Paper 72.

25) Susan C., Pamela J., Kathleen L. and Erin S., 2011, Evaluating land use and livelihood impacts of early forest carbon projects: Lessons for learning about REDD+.

26) Tacconi et al., 2012, The livelihood impacts of payments for environmental services and implications for REDD+: The Australian National University.

27) William D. S., Anne M. L., Amy E. D., Ida A.P. R., Thu B H., Abdon A. and Therese D., 2013, How are REDD+ proponents addressing tenure problems? Evidence from Brazil, Cameroon, Tanzania, Indonesia, and Vietnam World Development Vol. 55, pp. 37-52, 2014. 